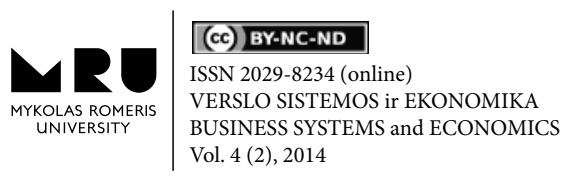

\title{
IMPACT OF RECESSION ON TOTAL REVENUE OF REGIONAL GOVERNMENTS IN RUSSIA
}

\author{
Natalia ERMASOVA \\ Governors State University \\ College of Business and Public Administration \\ 1 University Parkway, room C3340, University Park, IL 60484, U.S.A. \\ E-mail: nermasova@govst.edu \\ John L. MIKESELL \\ Indiana University \\ School of Public and Environmental Affairs \\ 1315 East Tenth Street, room 235, Bloomington, IN 47405 \\ E-mail: mikesell@indiana.edu \\ Sergey ERMASOV \\ Saratov State University \\ Finance Department \\ 85 Astrachanskaya street, Saratov, Russia, 410080 \\ E-mail: ermasov@mail.ru
}

doi:10.13165/VSE-14-4-2-03

\begin{abstract}
This study recounts the experiences of Russian regional governments in dealing with fiscal stress during the 2008-2012 period, a period of the most severe global economic downturn of the last seventy years. Much of the disparity is driven by differential endowments of energy resources and this diversity translates into highly diverse fiscal capacities and need for government services. Although regions do have some independent revenue-raising authority, all taxes are administered by the National Ministry of Taxation and a sizable share (roughly 45\%) of total national revenue is transferred to regional and local governments. The transfers, however, are not of equal importance to all regions. This research identifies what sorts of governments have faced the most fiscal stress, how shares of revenue from various sources shifted with the recession, and how the fiscal system responded to the recession. The following research questions are explored in the paper: (1) What sorts of governments have faced the most fiscal stress during the recession? What parts of the country have subnational governments in the greatest fiscal stress? Where was fiscal stress the greatest? (2) What factors have driven fiscal stress? (3) How have governments with the greatest stress dealt with fiscal stress? (4) How did revenue shares with the recession? Were certain sources more heavily impacted than others? (5) How did corporate income tax and personal income tax shares change with the recession? The intention of this paper is to expand knowledge of the attributes of the regional and local budgeting system in Russia and improve approaches for dealing with fiscal stress.
\end{abstract}

Keywords: financial crisis, regional budget, corporate tax, income tax, Russia. JEL classification: $\mathrm{H} 71, \mathrm{H} 72, \mathrm{H} 73$. 


\section{Introduction}

The economic crisis in Russian industry began in the autumn of 2008. Industrial production fell by $14 \%$ and GDP decreased by $11 \%$ in Russia in 2009. According to Bashkatova (2010), the peak of the recession came in May of 2009. Table 1 presents GDP, industrial production, and inflation indicators on a quarterly basis from 2008 through early 2013. These data confirmed in 2009 as the critical period for Russian economic activity, with real economic decline. Inflation was also lower in that year than in other years, not surprising in light of the slack in production growth rates.

Table 1: Russian economic activity by quarters, 2008 through 2013

\begin{tabular}{|c|c|c|c|c|}
\hline Period & $\begin{array}{l}\text { Nominal GDP, bln. } \\
\text { roub. }\end{array}$ & $\begin{array}{c}\text { GDP, } \% \text { to } \\
\text { corresponding } \\
\text { period }\end{array}$ & $\begin{array}{l}\text { Production index } \\
\text { for the key economic } \\
\text { activities, } \%\end{array}$ & $\begin{array}{l}\text { Deflator of } \\
\text { GDP, \% }\end{array}$ \\
\hline \multicolumn{5}{|l|}{2013} \\
\hline I & 14987,70 & 101,60 & 100,60 & 106,90 \\
\hline II & & 101,20 & 100,20 & \\
\hline \multicolumn{5}{|l|}{2012} \\
\hline $\mathrm{I}$ & 13490,60 & 104,90 & 105,00 & 110,10 \\
\hline II & 14571,10 & 104,00 & 103,20 & 107,40 \\
\hline III & 16349,50 & 103,00 & 102,40 & 108,40 \\
\hline IV & 17434,30 & 102,10 & 101,70 & 107,50 \\
\hline 2011 & 15461,70 & 104,80 & 105,60 & 113,30 \\
\hline I & 11679,90 & 104,00 & 105,60 & 116,80 \\
\hline II & 13038,50 & 103,40 & 104,00 & 117,90 \\
\hline III & 14405,60 & 105,00 & 106,70 & 115,80 \\
\hline IV & 15461,70 & 104,80 & 105,60 & 113,30 \\
\hline \multicolumn{5}{|l|}{2010} \\
\hline $\mathrm{I}$ & 9617,10 & 103,80 & 106,40 & 111,20 \\
\hline II & 10693,30 & 104,90 & 107,60 & 110,30 \\
\hline III & 11843,10 & 103,80 & 102,90 & 109,60 \\
\hline IV & 13019,30 & 104,90 & 106,40 & 114,80 \\
\hline \multicolumn{5}{|l|}{2009} \\
\hline $\mathrm{I}$ & 8334,60 & 90,80 & 86,20 & 103,40 \\
\hline II & 9244,80 & 88,80 & 86,00 & 101,60 \\
\hline III & 10411,30 & 91,40 & 90,00 & 98,70 \\
\hline IV & 10816,40 & 97,40 & 98,50 & 104,60 \\
\hline \multicolumn{5}{|l|}{2008} \\
\hline IV & 10618,90 & 108,39 & 97,10 & 109,80 \\
\hline III & 11542 & 109,20 & 109,10 & 121,80 \\
\hline
\end{tabular}

Source: Goscomstat Russia (Russian Federation Federal State Statistical Service), (2014)

The recession crisis was different in the economic regions of the country. It is possible to identify five groups of regions in terms of impact and to identify the major factor behind the impact (Table 2): 
(a) The group of regions that experienced the strongest and longest crisis include regions in which the bank sector and automotive industry is dominant. They suffered because of low competitiveness of the Russian automotive industry and reduced overall demand for automobiles.

(b) Regions dominated by the metallurgical industry suffered a strong and mediumterm prolonged crisis. The production index for the key economic activities decreased by $20-25 \%$ in these regions at the peak of the crisis in May of 2009 and conditions began to improve in the summer of 2009.

(c) Regions hosting international companies. These regions were less sensitive to overall Russian conditions and suffered a less deep and shorter decline.

(d) Regions with diversified industry and dependence of food industry. These regions were not severely affected by the recession. Areas dependent on the food industry benefitted from the expanding domestic market and a decline in food imports because of ruble devaluation.

(e) Oil producing regions. These regions felt just a little impact Big gas supplier regions (Yamal-Nenets Autonomous District, Astrakhan region) did suffer a considerable decline in economic activity because of problems with "Gazprom", the state gas utility, in 2009.

Table 2: Groups according to changes in regions' GDP per capita in 2008-2009

\begin{tabular}{|c|c|c|c|c|}
\hline Group & Regions in the group & $\begin{array}{l}\text { Number } \\
\text { of } \\
\text { regions } \\
\text { in the } \\
\text { group }\end{array}$ & $\begin{array}{l}\text { Ratio of } \\
\text { regional } \\
\text { GDP } \\
\text { in } 2009 \\
\text { relative } \\
\text { to } \\
\text { regional } \\
\text { GDP in } \\
2008\end{array}$ & $\begin{array}{l}\text { Characteristic } \\
\text { of the group }\end{array}$ \\
\hline $\begin{array}{l}\text { Group } 1- \\
\text { regions with the } \\
\text { strongest and } \\
\text { longest crisis }\end{array}$ & $\begin{array}{l}\text { Vologda, Samara, } \\
\text { Chelyabinsk, Lipetsk, } \\
\text { Kemerovo, Sverdlovsk, } \\
\text { Astrakhan regions, } \\
\text { Moscow, the Republic of } \\
\text { Bashkortostan, Perm krai, } \\
\text { Chuvash Republic }\end{array}$ & 11 & $0.72-0.89$ & $\begin{array}{l}\text { The regions made a lot of } \\
\text { products using advanced } \\
\text { innovation technology by } \\
\text { organizing processing divi- } \\
\text { sions of foreign manufac- } \\
\text { turers or by technological } \\
\text { modernization of } \\
\text { local producers. The auto- } \\
\text { motive and metallurgical } \\
\text { industries are dominant in } \\
\text { some of these regions. }\end{array}$ \\
\hline $\begin{array}{l}\text { Group } 2 \text { - } \\
\text { regions with } \\
\text { strong and } \\
\text { medium-term } \\
\text { prolonged crisis }\end{array}$ & $\begin{array}{l}\text { Moscow region, Volgograd, } \\
\text { Tyumen, Tula, Novosibirsk, } \\
\text { Oryol, Nizhny Novgorod, } \\
\text { Kaliningrad, Murmansk, } \\
\text { Belgorod regions, the } \\
\text { Republic of Karelia, } \\
\text { Chechen, Udmurt Republic, } \\
\text { the Republic of Tatarstan, } \\
\text { the Republic of Ingushetia }\end{array}$ & 15 & $0.9-0.95$ & $\begin{array}{l}\text { Mixed group of regions: (1) } \\
\text { regions dominated by the } \\
\text { industry using high tech- } \\
\text { nology. Regions with low } \\
\text { and middle level of invest- } \\
\text { ments risks; (2) regions } \\
\text { dominated with agriculture } \\
\text { (Chechen Republic and } \\
\text { Republic of Ingushetia) }\end{array}$ \\
\hline
\end{tabular}




\begin{tabular}{|c|c|c|c|c|}
\hline $\begin{array}{l}\text { Group } 3- \\
\text { regions with } \\
\text { less deep and } \\
\text { shorter decline }\end{array}$ & $\begin{array}{l}\text { Orenburg, Kursk, Ivanovo, } \\
\text { Omsk, Tomsk, Rostov } \\
\text { regions, the Republic of } \\
\text { Mordovia, Kirov, Kostroma, } \\
\text { Ivanovo, Yaroslavl regions, } \\
\text { the Republic of Buryatia }\end{array}$ & 14 & $0.96-0.99$ & $\begin{array}{l}\text { Balanced human resources, } \\
\text { capital resources and mar- } \\
\text { ket conditions. }\end{array}$ \\
\hline $\begin{array}{l}\text { Group } 4- \\
\text { regions not } \\
\text { severely } \\
\text { affected in the } \\
\text { recession }\end{array}$ & $\begin{array}{l}\text { Stavropol, Bryansk, } \\
\text { Saratov, Ryazan, Ulyanovsk } \\
\text { regions, Krasnoyarsk, } \\
\text { Khabarovsk, Krasnodar } \\
\text { krai, St. Petersburg, Penza, } \\
\text { Kurgan, Pskov, Novgorod, } \\
\text { Tver, Irkutsk, Smolensk } \\
\text { regions, Komi Republic, } \\
\text { Kaluga, Kostroma, the } \\
\text { Republic of Mari El, } \\
\text { Altai Republic, Vladimir, } \\
\text { Voronezh, the Republic } \\
\text { of Sakha, Karachay- } \\
\text { Cherkess Republic, Jewish } \\
\text { Autonomous region }\end{array}$ & 27 & $1-1.09$ & $\begin{array}{l}\text { Diversified industry. Not } \\
\text { among the leaders, but still } \\
\text { have a chance } \\
\text { for moving to more devel- } \\
\text { oped clusters, but this will } \\
\text { have to seriously upgrade } \\
\text { the education and produc- } \\
\text { tion base. }\end{array}$ \\
\hline $\begin{array}{l}\text { Group } 5- \\
\text { regions with no } \\
\text { decline }\end{array}$ & $\begin{array}{l}\text { Primorsky krai, Tambov, } \\
\text { Arkhangelsk, the Republic } \\
\text { of Adygea, Dagestan } \\
\text { Republic, Kabardino- } \\
\text { Balkaria, the Republic of } \\
\text { North Ossetia - Alania, } \\
\text { Khakassia Republic, } \\
\text { Amur region, Kamchatka, } \\
\text { Magadan, Primorskiy re- } \\
\text { gion, } \\
\text { Sakhalin region, Chukotka } \\
\text { Autonomous Okrug }\end{array}$ & 15 & $1.1-1.5$ & $\begin{array}{l}\text { Regions of far North and } \\
\text { the South, less developed } \\
\text { regions. }\end{array}$ \\
\hline
\end{tabular}

Source: prepared by the authors based on Goscomstat Russia (2014)

The following sections will examine how these problems in the Russian economy translated into issues for regional and local governments. In particular, these questions will be explored: (1) what sorts of governments have faced the most fiscal stress during the recession? What parts of the country have subnational governments in the greatest fiscal stress? Where was fiscal stress the greatest? (2) What factors have driven fiscal stress? (3) How have governments with the greatest stress dealt with fiscal stress? (4) How did revenue shares with the recession? Were certain sources more heavily impacted than others? (5) How did corporate income tax and personal income tax shares change with the recession?

\section{Budgeting structure in Russia}

Unlike the American experience, in which state and local governments pre-dated the founding of the national government, the Russian federal government created its subnational governments in 1996. The Russian Federation is a federal republic with a presiden- 
tial system of government since the dissolution of the Soviet Union in 1991. The Russian Federation, in accordance with Article 5 of the 1993 Constitution of Russia, consists of equal subjects of the Russian Federation with equal rights in their relations to federal authorities (Arts. 5.1 and 5.4). Each subject of the federation possesses its own foundation laws (constitutions for the republics, charters for all others), political institutions and legislation.

The Russian government has three layers: federal, regional and local. The 83 subjects of the federation includes the following: 21 republics, 46 oblasts (provinces), 9 krays (territories), 4 autonomous okrugs (areas), 1 autonomous okrugs and 2 federal cities of Moscow and Saint Petersburg (a policy of amalgamation reduced the number of subjects from the initial 89 in 2013). An additional layer - the Federal District - was created by President Putin in 2000, but the districts are not a constitutional part of the administrative-territorial division of the Russian Federation, and were created by analogy with military districts (Decree of the President of Russia Vladimir Putin № 849 "On the Plenipotentiary Representative of the President of the Russian Federation in the Federal District" on May 13, 2000). The Federal Districts have no revenue and expenditure authority, they are only for administrative supervision and control. There are more than 24,000 local governments, with dramatically different levels of economic strength, level of development, and institutional capacities. Moscow and Saint Petersburg (Cities of Federal Significance) are given separate special treatment (Skurikhina, 2012). The very existence of the Russian local government arises more from administrative convenience and outside pressure than from popular demand for independent local governments. Soviet-era local administrative districts ("raiones") are the primary geographic bases for the units of Russian local governments. The federal and regional governments charter Russian local governments. According to Ermasova (2008), the Budget Code adopted in 1998 put the budget process in Russia on a modern footing. It sets out the contents of the annual budget laws, defines the jurisdictions of the federal and regional governments and regulates their financial relations, prescribes the annual budget preparation and execution time schedule and lays down rules for the public debt. A revision in 2003 created the Oil Stabilization Fund and a 2004 revision reformed fiscal relations with the regions and prescribed fiscal rules for subnational governments. A federal law in 2003, "On General Principles of Local Self-Government", established a uniform and universal system of local government throughout the country.

The number of Russian local governments continues to increase and the geographical coverage expands. As a result of the transition to a two-level model of local government organization, the first level being municipal districts and city districts, the second - urban and rural settlements within municipal districts, the number of municipal entities in Russia more than doubled from 2005 to 2006, from 11,733 to 24,372. City districts are local governments in urbanized areas within the other regions. Municipal districts generally cover larger areas that range from urban to rural; these units resemble American counties in their geographic coverage (Zhuravskaia, 1998). The lower level units exist only within specific portions of municipal districts (Bird, 2000; Lavrov, Litwack and Sutherland, 2001; Boex and Martinez-Vazquez, 2005). They are urban and rural settlements, providing more localized services within municipalities to their populations. According to Kraan and Bergvall, etc. (2008), the most numerous type of municipality is the rural settlement (82\%), followed by urban settlements, municipal districts $(7.4 \%)$ and city district $(2.2 \%)$.

This structure may be explained with the following example. Belgorod oblast is one of the 83 regional governments. Within the Belgorod oblast, there are 309 primary localities, 
including 19 municipal districts, 3 urban districts, one of which is Belgorod city, 25 urban settlements and 262 rural settlements. The national government prescribes the responsibilities of these subnational governments and also assigns the revenue sources available to them. Article 3 of the Tax Code of the Russian Federation states that "the taxes and fees of the subjects of Russian Federation, local taxes and fees are established, amended or cancelled, accordingly, by the taxation and fee laws of the subjects of Russian Federation and normative legal acts of representative institutions of local government about the taxes and fees pursuant to the Tax Code of Russian Federation". Federal laws specify revenue authority, rate ranges, and allowable exemptions and deductions for each revenue source, and the Federation Ministry of Taxation administers them all. All taxes, regardless of whether they are federal, regional or local, are based on federal legislation. Within this federal framework, regional and local governments have a degree of autonomy within the constraints set by federal legislation concerning the rate structure, payment dates, and exemptions in regional and local taxation (Bird et al., 1995; Bird, 1999; Bird and Smart, 2001). Regional and local taxes go entirely to the regions or municipalities, while federal taxes go to different levels depending on the tax-sharing arrangement set in the federal legislation (Budget Code, 2008). Regions may share their tax revenues with local governments by establishing their own regional tax-sharing system. Municipal districts may do the same vis-à-vis their municipal settlements.

Article 12 of the Tax Code establishes limits on tax rates, as well as the order, time period of tax payment and reports for given regional or local taxes, within which the statutory (representative) bodies of the subjects of Russian Federation, or representative institutions of local government, may adopt taxes. Their revenue laws, last reformed in 2004, provided for greater source revenues of their own than previously until late 2008. A new article was introduced into the Budget Code (Art. 130) in 2008, setting up conditions and in some cases sanctions restricting regional budget policies. These restrictions aim to encourage regions to develop their own tax base and to improve fiscal discipline. The article distinguishes various categories of regions on the basis of the share of grants in their budget revenues. In terms of expenditure responsibilities, subnational governments have the normally expected assignments. Their role predominates for all education before higher education, housing, fire safety, agriculture and fishing, transportation, housing, environmental protection, health care and sport. The federal role is dominant in the judicial system, international relations, national defense, basic research, higher education and pensions (Treisman, 1996; Federal Treasury, 2012; Ministry of Finance, 2014).

\section{Revenues of regional governments}

Revenue capacity and exploitation of that capacity determine the fiscally sustainable spending limit, and Russia's difficulties with conversion to a market-based economy have created some revenue problems. A typical Russian region has one or two strong cities or districts that supply the vast majority of tax revenue, while most of the remaining districts, usually without any sort of real tax base, are financed primarily by the regional budget (OECD, 2000). Petroleum exports significantly supported other economic development, after some initial problems, although petroleum revenues do not provide a long-term, sustainable source for the future. Oil and gas revenues were most important tax revenues in consoli- 
dated budget in 2008-2012. During the recession, oil and gas revenues decreased from 10.6 of GDP in 2008 to $7.7 \%$ of GDP in 2009 and increased after the recession to $10.1 \%$ of GDP in 2012. As Table 3 shows, customs fees were the second most important source, equaling $8.6 \%$ of GDP in 2008, falling to $6.8 \%$ in 2009 and increasing to $8 \%$ in 2012.

Table 3: Revenues to the consolidated budget $^{1}, 2008-2012$, as $\%$ of GDP

\begin{tabular}{|l|c|c|c|c|c|}
\hline & $\mathbf{2 0 0 8}$ & $\mathbf{2 0 0 9}$ & $\mathbf{2 0 1 0}$ & $\mathbf{2 0 1 1}$ & $\mathbf{2 0 1 2}$ \\
\hline Corporate income tax & 6.1 & 3.3 & 3.8 & 4.1 & 3.8 \\
\hline Personal income tax & 4.0 & 4.3 & 4.0 & 3.6 & 3.6 \\
\hline $\begin{array}{l}\text { Insurance contributions to state pension, } \\
\text { medical and social security }\end{array}$ & 5.1 & 5.5 & 5.0 & 6.3 & 6.2 \\
\hline VAT & 5.1 & 5.3 & 5.5 & 5.8 & 5.7 \\
\hline Excise & 0.8 & 0.9 & 1.0 & 1.2 & 1.3 \\
\hline Tax on extraction of natural resources & 4.1 & 2.7 & 3.1 & 3.7 & 4.0 \\
\hline Customs fee & 8.6 & 6.8 & 7.0 & 8.3 & 8.0 \\
\hline Oil and gas revenues & 10.6 & 7.7 & 8.3 & 10.1 & 10.5 \\
\hline Total tax revenues & 34.3 & 36.5 & 37.7 & 43.1 & 43.1 \\
\hline
\end{tabular}

Source: prepared by the authors based on Goscomstat Russia (2014) and Ministry of Finance of Russia (2014)

Total revenues compared to GDP did increase dramatically in the post-recession years of 2011 and 2012, compared with both immediate pre-recession and recession years. The heavy reliance on customs fees and oil and gas revenue and oil tax revenue (52.2 percent of the total in 2012), however, is more consistent with a developing, extractive industry dependent economy than of a modern industrialized nation that relies more heavily on VAT and income taxes (Le Houerou, 1994; Craig, Norregaard and Tsibouris, 1997; MartinezVazquez and Timofeev, 2008). It may be assumed that such traditional border tax/extractive industry reliance represents a transition phase for the nation as it continues modernization.

\section{Regional revenues}

The shares of revenue from various sources differ between developed and less developed regions (Table 4). The mean of gross regional product (GRP) per capita at purchasing power parity in US dollars in Russia was $\$ 13,177$ in 2008 and $\$ 12,339$ in 2009. The regions that have GRP less than the mean were qualified as less developed regions; regions that have GRP higher than the mean were qualified as developed regions. There was the difference in 24.2 times between the region with the highest GRP (Tyumen region - \$50,853) and the region with the lowest GRP (the Republic of Ingushetia - \$2,099) in 2008; 23.3 times in 2009, and compared to 1998 when the difference was 17.08 times between the region with the highest GRP (Tyumen region - \$20,572) and the region with the lowest GRP (the Republic of Ingushetia - \$1,204). The disparity is great between regions, somewhat less in 2009 than in 2008 , but much greater than a decade earlier.

According to the Budgetary Code of the Russian Federation from July 31st, 1998, № 145, consolidated budget is the federal budget and the consolidated budgets of subjects of Russia. 
The most important two taxes are the profit tax and the personal income tax, both producing more than 30 percent of total tax revenue. National and regional corporate profit taxes are collected together, with the rate split into a 2 percent national rate and an 18 percent regional rate, although regional legislatures are permitted to reduce the rate to 13.5 percent for certain categories of taxpayers.

The personal income tax is only a subnational tax, with a flat 13 percent rate for all taxpayers, with 70 percent of revenue to regional budgets and 30 percent to local budgets. Excises and mineral extraction taxes are split between national and subnational budgets and property, vehicle, and land taxes are assigned to subnational budgets, but these taxes provide relatively small shares of total tax revenues. Recently, subnational revenues from the profits tax have fallen considerably, a problem for the governments because so much of their total tax revenue comes from that tax. The value-added tax is exclusively a federal tax.

The tax on personal income (PIT) provides the main contribution to regional revenues of the budget of developed regions (Table 4).

Table 4: Contrasting developed and less developed regions: revenues to the regional budget, 2008-2012, as \% of total revenue

\begin{tabular}{|l|c|c|c|c|c|c|c|c|}
\hline & $\mathbf{2 0 0 9}$ & $\mathbf{2 0 0 9}$ & $\mathbf{2 0 1 0}$ & $\mathbf{2 0 1 0}$ & $\mathbf{2 0 1 1}$ & $\mathbf{2 0 1 1}$ & $\mathbf{2 0 1 2}$ & $\mathbf{2 0 1 2}$ \\
\hline & $\begin{array}{c}\text { De- } \\
\text { veloped } \\
\text { regions }\end{array}$ & $\begin{array}{c}\text { Less de- } \\
\text { veloped } \\
\text { regions }\end{array}$ & $\begin{array}{c}\text { De- } \\
\text { veloped } \\
\text { regions }\end{array}$ & $\begin{array}{c}\text { Less de- } \\
\text { veloped } \\
\text { regions }\end{array}$ & $\begin{array}{c}\text { De- } \\
\text { veloped } \\
\text { regions }\end{array}$ & $\begin{array}{c}\text { Less de- } \\
\text { veloped } \\
\text { regions }\end{array}$ & $\begin{array}{c}\text { De- } \\
\text { veloped } \\
\text { regions }\end{array}$ & $\begin{array}{c}\text { Less de- } \\
\text { veloped } \\
\text { regions }\end{array}$ \\
\hline $\begin{array}{l}\text { Corporate } \\
\text { income tax }\end{array}$ & 28 & 18 & 31 & 19 & 33 & 21 & 34 & 21 \\
\hline $\begin{array}{l}\text { Personal income } \\
\text { tax }\end{array}$ & 32 & 43 & 29 & 38 & 28 & 37 & 27 & 36 \\
\hline
\end{tabular}

Source: prepared by the authors based on Goscomstat Russia (2014) and Ministry of Finance of Russia (2014)

Figure 1: Dynamic of Personal Income tax and Corporate Income tax in Less Developed Regions in 2009-2012

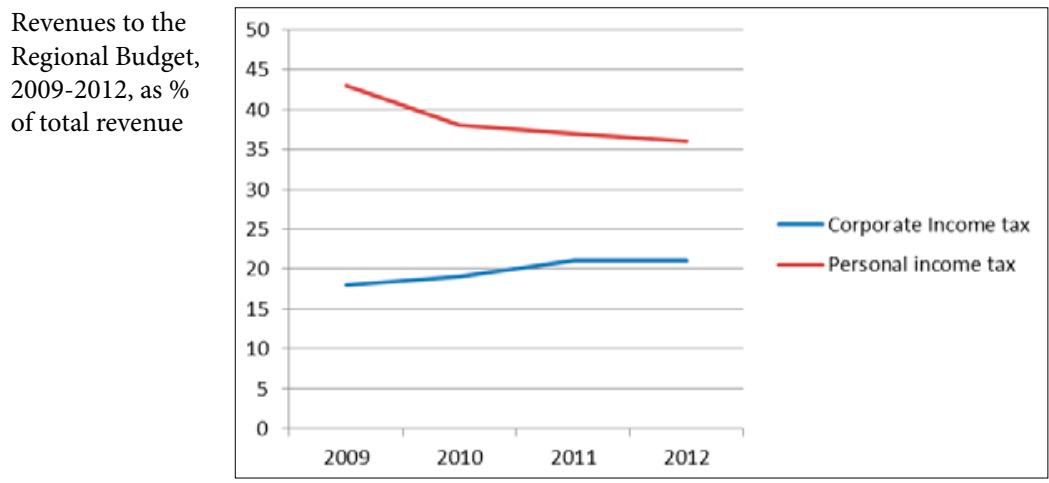

Source: Figure prepared by authors based on Goscomstat Russia (2014) and Ministry of Finance Russia (2014). 
Figure 2: Dynamic of Personal Income tax and Corporate Income tax in Developed Regions in 2009-2012

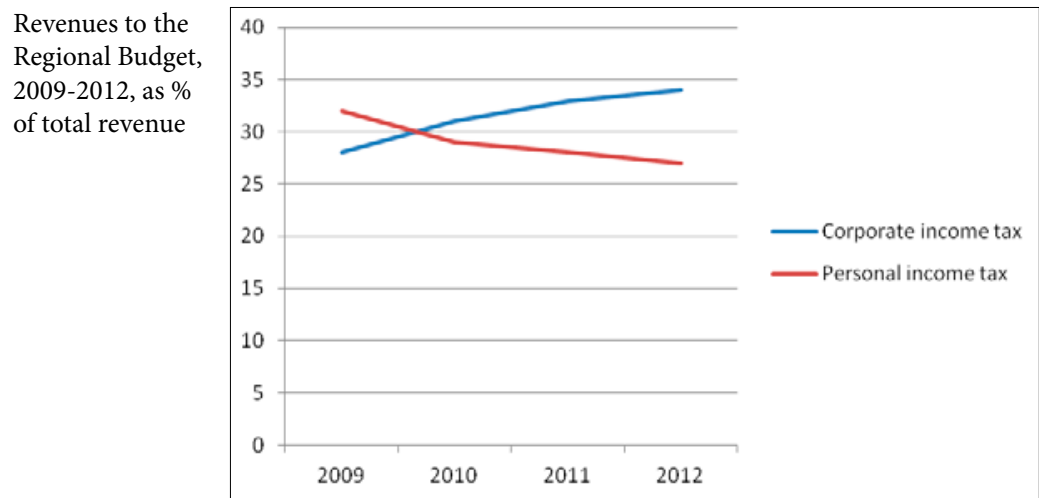

Source: Figure prepared by authors based on Goscomstat Russia (2014) and Ministry of Finance Russia (2014).

Income tax on personal income brought most of the tax revenue, just as in previous years: $66.4 \%$ of total revenue or 583.5 billion rubles in 2011 (in $2010-65.1 \%$ or 525.2 billion rubles; in $2009-68.7 \%$ or 494.6 billion rubles, in $2008-68.6 \%$ or 494.1 billion rubles). Differences in the share of personal income tax in total regional revenues were around the same for developed regions, ranging from $42 \%$ to $46 \%$. In less developed regions, the share of personal income tax ranged from $11 \%$ to $25 \%$ in $2005,35 \%$ to $37 \%$ in $2009,35 \%$ to $43 \%$ in 2012, except for the Republics of Chechnya (8.3\% in 2005, $75.8 \%$ in $2009,61.2 \%$ in 2012 ), Ingushetia $(5.8 \%$ in $2005,63.6 \%$ in $2009,49.2 \%$ in 2012$)$, Dagestan (9.3\% in $2005,40.5 \%$ in $2009,39.7 \%$ in 2012 ) and Altai (17.6\% in $2005,48 \%$ in 2009 , $44 \%$ in 2012 ) with a predominance of illegal employment (26\% in comparison to $39.2 \%$ on average in the Russian Federation (Zubarevich, 2011; Research Center of Regional Economics, 2011; Ministry of Finance, 2014). During the Great Recession and after economic downturn, the personal income tax share of total revenue declined in most regions by $3-5 \%$ from 2009 to 2012 .

The average share of corporate income tax in total regional revenue has followed a U-shape over time: the share was $31.8 \%$ in $2005,28.3 \%$ in $2008,25.2 \%$ in 2009 and $30.1 \%$ in 2012. The corporate income tax share is higher in more industrially developed regions (Krasnoyarsk region, Tyumen region, Yamal-Nenets Autonomous Okrug, Perm Krai and Sakhalin). During and after the economic downturn, the corporate income tax as a share of total revenue increased from 2005 to 2012 in all less developed regions. The situation was different in developed regions. The corporate income tax as a share of total revenue decreased from 2005 to 2009 and after that increased from 2010 to 2012 in the developed regions (Figure 2).

For example, the corporate income tax as a share of total revenue decreased from $28.5 \%$ in 2005 to $20 \%$ in 2009 and after that increased from $25 \%$ in 2010 to $29 \%$ in 2012 in Tomsk region. The same pattern appeared in Tyumen region $-66.8 \%$ in $2005,40 \%$ in 2009 , $70 \%$ in 2012 , Moscow region - from $35 \%$ to $38.8 \%$, Vologda region - $39.5 \%$ in $2005,17.2 \%$ in $2009,25 \%$ in 2012 . 
The highest corporate income tax share was in Tyumen region (73\% in 2011, compared with an average of all Russian regions of 25\%). Oil and gas companies in Russia pay tax at a place of "registration", without any effort to divide or apportion revenues according to place of operations, an important reason for this high share. Other high shares are for Khanty-Mansi (34\%), Yanal-Nenets Autonomous Okrug (37\%), Perm Krai (31\%) and Sakhalin (32\%). The company "Norilsk Nickel" paid corporate income tax that accounted for $37 \%$ of total revenues in Krasnoyarsk region in 2011 (Research Center of Regional Economics, 2011). Moscow had very high shares of corporate income tax in total revenues before recession (48\% in 2008). During the recession, the share of corporate income taxes in total tax revenues increased sharply and reached 33\% in developed regions in 2011. The corporate income tax yields less than $15 \%$ of the budget in regions of the Far East and some depressed regions (the Republic of Tuva, Altai Republic, Jewish Autonomous region). The corporate income tax revenue showed a large decline in 2009 and uneven growth across regions in 2010-2011. Regions dependent on metallurgy showed the worst performance (Vologda oblast - $45 \%$ below the pre-recession earnings, Lipetsk - 30\% below the pre-recession earnings, and Chelyabinsk - 33\% below the pre-recession earnings). They are followed by Tula and Volgograd regions (17-20\%), Nizhny Novgorod, Kostroma region and Perm (6-10\%) (Research Center of Regional Economics, 2011; Ministry of Finance, 2014).

Reduced corporate income tax revenue meant that the regions had low or negative tax revenue growth. In many less developed regions, the corporate income tax as a share of total revenue increased from $11-16 \%$ in 2009 to $14-30 \%$ in 2012. Exceptions included KarachayCherkessia (25.3\% in 2009 to $16.7 \%$ in 2012), Dagestan republic (25\% to $16.3 \%$ ), Kalmykia (20.1\% to $8.2 \%)$.

In regions producing alcohol and beer (Kaluga, Tula, Tver, Novosibirsk, KabardinoBalkaria) and petroleum products (Omsk, Yaroslavl, Bashkortostan), the share of revenue from excise taxes was two to three times higher than the Federation average of 5\%. During the recession, the share of revenue excise taxes increased 2-2.5 times in these regions. On average across the Russian Federation, 9\% of total tax revenue comes from the property tax. Shares are considerably higher in regions with energy steel companies: Tyumen, Lipetsk, Chelyabinsk, Sverdlovsk, Astrahan, Omsk, Yaroslavl and Perm regions. This tax has also become an important revenue source for the Moscow region (14\%) because of shopping and logistics centers (Research Center of Regional Economics, 2011).

During the recession, corporate income tax had the biggest decrease in 2009 (71.1\%). Since bottoming out in 2010, corporate tax revenues have once again begun to grow, but are still far from being fully recovered. The structure of local budget tax revenues did not change during the economic decline.

Non-tax revenue declined by $19.3 \%$ in 2009 . The major decrease was due to the reduction of income from the property, which is municipal property, compared to 2008 by $8.2 \%$ and revenue from sales of tangible and intangible assets $-26.1 \%$. In summary, real revenues of local budgets collapsed by $9.8 \%$ in 2009 . The biggest source of this collapse was from corporate income tax, which fell by $28.9 \%$.

Any efforts to provide citizens of the Russian Federation approximately comparable fiscal endowment for the provision of subnational government services would require extremely aggressive transfer programs (OECD, 2000; Skurikhina, 2012; Gaidar Institute for Economic Policy, 2014). 
A high degree of variance does exist across different subjects of the federation according to the share of federal transfers in aggregate subnational (consolidated regional) revenue. Voorhees (1998) found that "from 1992 to 1994, the maximum aid a region received increased from a high of 9.4 times the average to 24.9 times the average [...] it does appear that de-equalization is taking place among the subnational governments of the Russian Federation." While transfers account for less than 10 percent of the revenues of many subjects of the federation, this measure reaches 50-60 percent for over 20 of the least developed regions in 2000 (Lavrov, 2001). During the recession, the inequality of transfer system increased. For example, in 2011, the subsidies to balance of budget accounted for $39 \%$ of all revenues of the Republic of Chechnya, exceeding 2.5 times the share of subsidies to balance of budget in the Chukotka Autonomous Area - 22\% and in the Tyumen region - $15 \%$ of all revenues.

The transfers, however, are not of equal importance to all regions, as illustrated by the two programs. In 2011, budget-balancing subsidies accounted for 39\% of all revenues of the Republic of Chechnya, 22\% in the Chukotka Autonomous Area and 15\% in the Tyumen region, substantial sums that could either reduce or widen regional disparities. Investment subsidies from the federal level (e.g., subsidies for the implementation of federal target programs (FTP) and subsidies for investment in capital construction projects in regions) averaged $2 \%$ of regional budget revenue, but in the Kaliningrad region a share of investment subsidies in total revenues in regional budget reaches $24 \%$, in Ingushetia and Chechnya 16-18\%, in the Primorsky Krai and Mordovia - 13-14\%, in Dagestan, Kabardino-Balkaria, Tatarstan - 11-12\% of total revenues.

Other transfers are distinguished by a number of different purposes (coverage of cost of drugs for poor people, an additional payment for police support in mining towns, etc.). These transfers were 151 billion rubles. Besides Moscow, major recipients of other transfers were Yamal-Nenets Autonomous Okrug (15 billion rubles, or $11 \%$ of revenues in its budget), Sakhalin region ( 2 billion rubles, or $4 \%$ of its budget revenues), Khanty-Mansi Autonomous District and Kemerovo region (1.3-1.6\% of revenues).

During the economic decline, the federation increased the transfers from $1617 \mathrm{bln}$. rub. in 2009 to 1768 bln. rub. in 2011 to cover the deficit of regions (Table 6). During the economic decline, there was the growth of transfers (by $47 \%$ in 2008-2011) on regional level. The federal government sharply increased the amount of transfers to regions at the peak of the crisis in 2009 (by 34\% compared to 2008). The level of subsidies to the budgets in 2011 varied from 8\% in the Khanty-Mansi Autonomous District and 9\% in Saint Petersburg to $87 \%$ in the Chechen Republic and $84 \%$ in Ingushetia. In general, differentiation is relatively stable, although in 2011 there were some changes. First, subsidized budget has grown substantially in the "rich" regions: Moscow (from 4\% to 11\%) and the YamalNenets Autonomous Okrug (from 7\% to 14\%) and significantly less in Khanty-Mansiysk (from $5 \%$ to $8 \%$ ). These regions have been allocated specific additional transfers, even if these regions had the increase of incomes in their own budgets (Table 5). Also, Krasnodar region received a higher share of federal transfers in budget (from $25 \%$ to $31 \%$ ) due to the increased investment in future Sochi Olimpiada project. 
Table 5: Structure of financial aid to regions

\begin{tabular}{|l|c|c|c|c|c|c|}
\hline & \multicolumn{2}{|c|}{$\mathbf{2 0 0 9}$} & \multicolumn{2}{c|}{$\mathbf{2 0 1 0}$} & \multicolumn{2}{c|}{$201 \mathbf{1}$} \\
\cline { 2 - 7 } & $\begin{array}{c}\text { Bln. } \\
\text { roub. }\end{array}$ & $\mathbf{\%}$ & $\begin{array}{c}\text { Bln. } \\
\text { roub. }\end{array}$ & $\mathbf{\%}$ & $\begin{array}{c}\text { Bln. } \\
\text { roub. }\end{array}$ & $\mathbf{\%}$ \\
\hline Transfers, total & 1617 & $\mathbf{1 0 0}$ & 1511 & $\mathbf{1 0 0}$ & 1768 & $\mathbf{1 0 0}$ \\
\hline Subsidies & 579 & $\mathbf{3 6}$ & 524 & $\mathbf{3 5}$ & 565 & $\mathbf{3 2}$ \\
\hline $\begin{array}{l}\text { Including subsidies to equalize fiscal } \\
\text { capacity }\end{array}$ & 372 & $\mathbf{2 3}$ & 398 & $\mathbf{2 6}$ & 398 & $\mathbf{2 3}$ \\
\hline Including subsidies to balance the budget & 192 & $\mathbf{1 2}$ & 106 & $\mathbf{7}$ & 154 & $\mathbf{9}$ \\
\hline Other subsidies & 531 & $\mathbf{3 3}$ & 414 & $\mathbf{2 7}$ & 515 & $\mathbf{2 9}$ \\
\hline Subventions & 285 & $\mathbf{1 8}$ & 379 & $\mathbf{2 5}$ & 338 & $\mathbf{1 9}$ \\
\hline Other transfers & 85 & $\mathbf{5}$ & 72 & $\mathbf{5}$ & 215 & $\mathbf{1 2}$ \\
\hline Investment subsidies & 20 & $\mathbf{1}$ & 20 & $\mathbf{1}$ & 115 & $\mathbf{7}$ \\
\hline $\begin{array}{l}\text { Grants from the State Corporation Fund } \\
\text { of assistance to reforming housing and } \\
\text { communal services }\end{array}$ & 111 & $\mathbf{7}$ & 93 & $\mathbf{6}$ & 24 & $\mathbf{1}$ \\
\hline
\end{tabular}

Source: prepared by the authors based on Goscomstat Russia (2014) and Ministry of Finance of Russia (2014)

Also, there were conflicting trends: Magadan region, Irkutsk region, Yakutia and Adygea received less the proportion of transfers in the budgets due to the increase in their income in regional budgets. It proves again that there is no universal formula for financial aid for regions. It is a political game. According to Boex and Martinez-Vazquez (2005, p.8), "grant resources may be directed to stem negative political pressures, such as jurisdictions that did not support the executive in the previous elections, or "trouble-makers" such as secessionist jurisdictions (for instance, the ethnic republics in the Russian Federation)." Regions with a share of grants exceeding 60\% (excluding subventions) are subject to the strict restrictions. These regions should: $a$ ) conclude an agreement with the Federal Ministry of Finance of the Russian Federation on how to increase the efficiency of the budget expenditures; $b$ ) open and run special accounts in the units of the Federal Treasury for their transactions; $c$ ) ask once a year for an external audit of annual reports on budget execution to be carried out by the Accounts Chamber of the Russian Federation or by the Federal Service of Financial and Budgetary Control and Supervision (Research Center of Regional Economics, 2011; Ministry of Finance, 2014).

\section{Conclusion}

Not all Russian subnational governments faced the same revenue impacts during the recession of 2009. The group of regions in which the automotive industry and the metallurgical industry are dominant felt the greatest revenue impact. These include Vologda region, Samara region, Volgograd region, Vologda oblast, Lipetsk region, Chelyabinsk region, the Republic of Bashkorstan, Kemerovo region, Sverdlovsk region, Tula region, Udmurt Republic, Novosibirsk Oblast (Zubarevich, 2011). In comparison, developed regions with diversified industry (Murmansk region, Orenburg region, the Republic of Tatarstan, Krasnoyarsk region, Belgorod region, Kursk region, Penza region, Saratov region, Rostov region, Tambov region) and the oil producing regions only felt little impact of recession. 
These regions are generally in the Far East and Trans-Baikal. There was almost no decline in the leading oil producing regions during the crisis (Sakhalin region, Nenets Autonomous District, Khabarovsk region). Oil and gas revenues were the most important tax revenues in consolidated budget in 2008-2012. During the recession, oil and gas revenues decreased from 10.6\% of GDP in 2008 to $7.7 \%$ of GDP in 2009 and increased after recession till $10.1 \%$ of GDP in 2012. The customs fees were the second most important source, equaling $8.6 \%$ of GDP in 2008, falling to 6.8\% in 2009 and increasing to 8\% in 2012 (Zubarevich, 2011).

The tax on personal income (PIT) provides the main contribution to regional revenues of the budget of developed regions (35-39\%). The next important source of regional revenue is the corporate income tax. This tax brings around $25-35 \%$ in less developed regions and $40-50 \%$ in developed regions. It was the reason of budget shortfall during the financial crisis 2008-2009 when the corporate income tax revenue showed a large decline in 2009 and uneven growth across regions in 2010-2011. This tax also was the reason that the real revenues of local budgets collapsed by $9.8 \%$ in 2009 . The biggest source of this collapse was from corporate income tax, which fell by $28.9 \%$.

The operation of the Russian revenue system, combined with the considerable range in economic capacity of the regions, gives some regions enormous revenue advantages in comparison with others. Neither revenue nor transfer systems provide a balancing from the differences in economic capacity. This disparity means that the residents of regions with high resource endowment will receive substantially greater services from their government than will those in regions with lower endowment. If the Russian government seeks a system with a more balanced opportunity for all its citizens, without regard to where they might live in the country, its fiscal treatment of the regions would need to change. Because it is difficult to change the basic economic resource endowment with a tax structure, any change would need to come through aggressive base equalization transfers, transfers designed to provide substantially greater resources per capita to regions that are less resource rich - those resource endowments are the product of geographic accident and not special productivity of the residents of those regions. The transfer system would need to be clearly defined as redistributive and not subject to political overrides or negotiations. In the absence of such a revision, the disparities will continue and some regions will be dramatically more vulnerable to economic decline than others and the leaders of these vulnerable regions will lack tools to correct the results of any declines.

\section{References}

Bashkatova, A. (2010). Crisis in Russia Frightened the World Bank. Retrieved March 14, 2014 from http://www.ng.ru/economics/2010-02-05/1_crisis.html.

Bird, R. (1999). Rethinking Subnational Taxes: A New Look at Tax Assignment. IMF Working Paper. WP/99/165. Retrieved February 24, 2014 fromhttp://www.imf.org/external/pubs/ft/wp/1999/ wp99165.pdf.

Bird, R. (2000). A Perspective on Fiscal Federalism in Russia. CEPRA, Ottawa, November. Retrieved February 24, 2014 from http://www.frpii.org/english/Portals/0/Library/Inter-Governmental/A\%20 Perspective\%20on\%20Fiscal\%20Federalism\%20in\%20Russia.pdf.

Bird, R., and Smart, M. (2001). Intergovernmental Fiscal Transfers: Some Lessons from International Experience. Symposium on Intergovernmental Transfers in Asian Countries: Issues and Practices, Asian Tax and Public Policy Program. Tokyo, Japan: Hitotsubashi University. Retrieved February 24, 2014 from http://wwwl.worldbank.org/publicsector/learningprogram/Decentralization/IFTLessons.pdf. 
Bird, R., Ebel, R.D., and Wallich, C. (eds.). (1995). Decentralization of the Socialist State. Washington: World Bank.

Boex, J., and Martinez-Vazquez, J. (2005). The Determinants of the Incidence of Intergovernmental Grants: A Survey of the International Experience. International Studies Program Working Paper Series. Andrew Young School of Policy Studies Research Paper Series. Retrieved February 24, 2013 from http://aysps.gsu.edu/publications/2006/index.htm.

Budgetary Code Russian Federation. (2014). Retrieved January 24, 2014 from http://bk-rf.ru/8/56.html. Central Intelligence Agency. (2013). World Factbook: Russia. Retrieved January 24, 2014 from https:// www.cia.gov/library/publications/the-world-factbook/geos/rs.html.

Craig, J., Norregaard, J., and Tsibouris, G. (1997). Russian Federation. Fiscal Federalism in Theory and Practice. In T. Ter-Minassian (ed.), Fiscal Federalism in Theory and Practice (680-696). Washington: IMF.

Gaidar Institute for Economic Policy. (2014). The Results of Execution of Consolidated Budgets of Regions of the Russian Federation in 2013. Retrieved February 24, 2014 from http://www.iep.ru/en/comments/itogi-ispolneniia-konsolidirovannykh-biudzhetov-subektov-rf-v-2013-g.html.

Ermasova, N. (2008). Budget System of Russia. Moscow: URAIT.

Federal Tax Service Russia. (2014). Regional Tax and Non Tax Revenue. Retrieved August 23, 2014 from http://analytic.nalog.ru/portal/index.en-GB.htm.

Federal Treasury. (2012). Financial Reports, Government of the Russian Federation, Moscow.

Retrieved August 23, 2014 from http://www.roskazna.ru/byudzhetov-subektov-rf-i-mestnykh-byudzhetov/.

Goscomstat Russia. (2014). Regional Budgets. Retrieved August 23, 2014 from http://www.gks.ru/wps/ $\mathrm{wcm} /$ connect/rosstat_main/rosstat/ru/statistics/.

Kraan, D., Bergvall, I., Hawkesworth, J., Kostyleva, V., and Witt, M. (2008). Budgeting in Russia. OECD Journal on Budgeting, 8(2): 1-58.

Lavrov, A., Litwack, J., and Sutherland, D. (2001). Fiscal Federalist Relations in Russia:

A Case for Subnational Autonomy. Organisation for Economic Co-operation and Development. MPRA Paper No. 26537. Retrieved January 9, 2013 from http://mpra.ub.uni-muenchen.de/26537/.

Le Houerou, P. (1994). Decentralization and Fiscal Disparities among Regions in the Russian Federation. Washington: World Bank Institute.

Martinez-Vazquez, J., and Boex, J. (2001). Russia's Transition to a New Federalism. Washington: World Bank Institute.

Martinez-Vazquez, J., and Timofeev, A. (2008). Regional-Local Dimension of Russia's Fiscal Equalization. Journal of Comparative Economics, 36: 157-176.

Ministry of Finance. (2010). Information on the Results of the Monitoring of the Local Budget. Retrieved October 23, 2013 from http://www1.minfin.ru/ru/reforms/local_government/monitoring/.

Ministry of Finance. (2014). Public Debt Management Policy of the Russian Federation for 2012 - 2014. Retrieved August 23, 2014 from http://wwwl.minfin.ru/common/img/uploaded/library/2011/09/ Debt_policy_2012-2014.pdf.

OECD. (1997). Managing across Levels of Government. Paris: OECD.

OECD. (1997). OECD Economic Surveys: The Russian Federation. Paris: OECD.

OECD. (2000). OECD Economic Surveys: The Russian Federation. Paris: OECD.

RIA-Analytics. (2013). Ranking of Regions of Debt Ratio in 2012. Рейтинг регионов России по уровню долговой нагрузки. Retrieved September 1, 2014 from http://riarating.ru/regions_rankings/20120314/594065026.html.

Research Center of Regional Economics. (2011). Balance the Interests of Participants in the Budget Process to Be Restored. Retrieved September 1, 2014 from http://www.rg.ru/2011/07/05/budjet.html.

Shleifer, A., and Treisman, D. (1999). Without a Map: Political Tactics and Economic Reform in Russia. Cambridge: MIT Press.

Skurikhina, T. (2012). The Concept of Local Budget and Methods to Ensure Its Balance. Scientific Bulletin of the Ural Academy of Public Administration: Politology, Economics, Sociology, Law, 1(17): 45-57. 
Treisman, D. (1996). The Politics of Intergovernmental Transfers in Post-Soviet Russia. British Journal of Political Science, 26(2): 299-335.

Voorhees, W. (1998). The 1994 Federal Fund for Financial Support to Russian Subnational Governments: A Case of De-equalization? Retrieved September 1, 2014 from www.researchgate.net.

Zhuravskaia, E. (1998). Incentives to Provide Local Public Goods: Fiscal Federalism, Russian Style. Mimeo: Harvard University.

Zubarevich, N. (2011). Monitoring of the Crisis and Post-crisis Development of Russian Regions.Institute of Social Policy. Retrieved September 1, 2014 from http://www.socpol.ru/atlas/overviews/social_ sphere/kris.shtml.

\title{
EKONOMINIO NUOSMUKIO POVEIKIS REGIONŲ VALDŽIOS BENDROSIOMS PAJAMOMS RUSIJOJE
}

\author{
Natalia ERMASOVA \\ Verslo ir viešojo administravimo kolegija, Governors valstijos universitetas, \\ Jungtinès Amerikos Valstijos \\ John L. MIKESELL \\ Viešųjų reikalų ir aplinkos apsaugos mokykla, Indianos universitetas, \\ Jungtinès Amerikos Valstijos \\ Sergey ERMASOV \\ Saratovo valstybinis universitetas, Rusija
}

Santrauka. Šis straipsnis atskleidžia Rusijos regionų valdžios patirtị sprendžiant fiskalinius sunkumus 2008-2012 metų laikotarpiu, kuris laikomas bene didžiausiu pasaulinės ekonomikos nuosmukiu per pastaruosius septyniasdešimt metų. Daug skirtumų tarp regionų atsiranda dèl nevienodų energijos išteklių ir ši ịvairovè suponuoja nevienodus fiskalinius pajėgumus ir vyriausybès paslaugų poreikị. Nors regionai turi šiek tiek nepriklausomą pajamų didinimo galimybę, tačiau visi mokesčiai yra administruojami nacionalinès Mokesčių ministerijos ir nemaža dalis (maždaug $45 \%$ procentų) visų nacionalinių pajamų yra pervedami regionų ir vietos valdžios institucijoms. Tačiau tokie pervedimai nèra vienodai svarbūs visuose regionuose. Šis tyrimas identifikuoja, kurių sričių valdžia susidūrè su didžiausiais fiskaliniais sunkumais, kaip pasikeite pajamų, gaunamų iš skirtingų šaltinių, dalis nuosmukio metu ir kaip fiskalinès sistemos reagavo ị nuosmukị. Straipsnyje yra išnagrinèti šie tyrimo uždaviniai: (1) Kokio lygio valdžia susidūrè su didžiausiais fiskaliniais sunkumais ekonominio nuosmukio metu? Kuriose šalies dalyse subnacionalinio lygmens valdžia patyre didžiausius sunkumus fiskalinio nuosmukio metu? Kur buvo didžiausias fiskalinis sunkmetis? (2) Kokie veiksniai lèmé fiskalinius sunkumus? (3) Kaip vietinè valdžia sprende fiskalinius sunkumus? (4) Koks buvo nuosmukio poveikis pajamoms? Ar tam tikri pajamų šaltiniai patyrè didesnę ịtaką nei kiti? (5) Kaip pelno mokesčio ir gyventojų pajamų mokesčio dalys pakito nuosmukio laikotarpiu? Šio darbo tikslas yra plèsti žinias apie regioninių ir vietos biudžetų sistemas Rusijoje ir pagerinti fiskalinių sunkumų sprendimo būdus.

Reikšminiai žodžiai: finansų krizė, regioninis biudžetas, pelno mokestis, pajamų mokestis, Rusija. 